\title{
Van weelde naar waarde
}

\section{Cubaanse lessen voor de (ouderen)zorg}

\author{
Jet Bussemaker · Anneke Kramer
}

Published online: 2 November 2020

(c) The Author(s) 2020

Samenvatting De Nederlandse zorg behoort tot de beste van de wereld. Toch is er onvrede, vooral in de eerste lijn. Vijf jaar na de decentralisatie komt de samenwerking tussen zorg en welzijn nog steeds maar moeizaam op gang. Het lukt ons niet meer te doen aan preventie, terwijl dat in het kader van gezondheidsbevordering en kostenbeheersing noodzakelijk is. Zorgmedewerkers ervaren weinig professionele ruimte en veel administratieve werkdruk, en willen minder gaan werken. Een alarmerend vooruitzicht, gezien de vergrijzing. Is het mogelijk tegen deze achtergrond inspiratie op te doen in een land waar men een fractie uitgeeft van de Nederlandse zorgkosten en dat een tekort kent aan medicijnen en instrumenten? Ja, dat kan, zo zagen we in Cuba, toen een multidisciplinaire groep gezondheidswerkers (in opleiding) daar in januari op studiereis was. De groep kreeg veel energie van de Cubaanse aanpak gericht op preventie en gezondheidsbevordering, kleinschalige, integrale zorg en een organisatie die dat ondersteunt. In dit artikel schetsen we de gezondheidszorg in Cuba aan de hand van onze ervaringen, met een focus op de ouderenzorg, en vergelijken deze met Nederland.

Trefwoorden preventie gezondheidszorgsysteem . geïntegreerde zorg · Cuba

J. Bussemaker

LUMC, Universiteit Leiden, Governance Faculteit, Leiden, Nederland

A. Kramer $(\square)$

LUMC, Leiden, Nederland

a.w.m.kramer@lumc.nl
Abstract The Dutch healthcare system is one of the best of the world. However, there are challenges especially in primary care. The collaboration between healthcare and wellbeing is still poor, despite policyintentions. Although prevention may increase health promotion and cost reduction, we do not succeed. Healthcare professionals experience administrative burdens and want to decrease working hours, an alarming prospect in relation to an aging society. Against this background a multidisciplinary group of healthcare providers (in training) got inspired by the healthcare system of Cuba. Cuba spends a fraction of healthcare costs compared to the Netherlands, focusing on prevention, small scale integrated care and organizational support. In this paper we present some lessons from Cuban healthcare.

Keywords Prevention - Healthcare system . Integrated care $\cdot$ Cuba

\section{Preventie en integrale zorg in Nederland en Cuba}

In Cuba ligt de nadruk op collectieve preventie, gericht op de familie en de buurt. Hier in Nederland beperkt het collectieve preventiebeleid zich echter tot de jeugd. Via consultatiebureaus en de jeugdgezondheidszorg volgen we de gezondheidsontwikkeling van jongeren. Weliswaar valt preventie van ouderen onder de Wet Publieke Gezondheid, maar een herkenbare collectieve aanpak ontbreekt. Gemeenten leggen in hun gezondheidsbeleid geregeld een relatie tussen taken in het kader van de Wet maatschappelijke ondersteuning en publieke gezondheid, maar een integrale aanpak is zeker geen gemeengoed. Wat verder opvalt is de focus op individuele gedragsverandering, vooral ten aanzien van roken, drinken en eten. Via voorlichting (drinken, roken, eten), financiële prikkels (roken) en gebodsbepalingen (roken en drinken onder 18 jaar) 
probeert de overheid onze individuele leefstijl te veranderen. Het Nationaal Preventieakkoord uit 2018 zet een volgende stap. Het benoemt de samenhang van gezondheid met zaken als werkloosheid, schulden en eenzaamheid. De uitwerking spitst zich echter vooral toe op individuele gedragsverandering. Preventie blijft een individuele verantwoordelijkheid. Ook in de huisartsgeneeskunde ligt de nadruk op gezondheidsbevordering van het individu.

De laatste jaren zien we initiatieven om over schotten heen te komen tot een meer wijkgerichte en integrale aanpak, zoals Welzijn op Recept en de preventiecoalities. Een van ons is betrokken bij het project Gezond en Gelukkig Den Haag, waarin we proberen het sociale en medische domein samen vorm te geven in een gezondewijkaanpak. Ondanks mooie voorbeelden signaleren we dat fragmentatie in beleid en financiering vooralsnog een grote doorbraak in wijkgericht werken belemmert.

In Cuba heeft men, na de revolutie van 1959, een omvattend preventie- en gezondheidsbeleid ontwikkeld. De kindersterfte daalde sterk (in 2019 $4,4 / 10.000$ ) en is daarmee vergelijkbaar met die in Nederland (3,5); de gemiddelde levensverwachting steeg tot bijna 79 jaar en komt daarmee in de buurt van die van Nederland $(81,5$ jaar) $[1,2]$. Dat is voor een ontwikkelingsland een enorme prestatie. Het $\mathrm{Cu}-$ baanse preventiebeleid kent een collectieve aanpak, gericht op de gehele bevolking. Dat vertaalt zich in een integrale benadering van gezondheidsbevordering met laagdrempelige en kleinschalige voorzieningen in de wijk, gericht op medische, psychische en sociale factoren. Om een beter beeld te krijgen van die collectieve aanpak van preventie en gezondheid beschrijven we eerst hoe de gezondheidszorg in Cuba werkt en gaan we vervolgens dieper in op preventie bij ouderen.

\section{Gezondheidszorg in Cuba}

De wijkverpleegkundige en de huisarts vormen de spil van de Cubaanse gezondheidszorg. Op elke duizend inwoners is er één consultorio medico de la familia. Idealiter wonen de wijkverpleegkundige en huisarts bij hun praktijk. Elke consultorio heeft zijn eigen buurt, is laagdrempelig toegankelijk en onderhoudt nauwe contacten met andere voorzieningen in de buurt, zoals de school of de straatcoördinator. Er zijn spreekuren en er worden huisbezoeken gedaan. Wijkverpleegkundige en huisarts verdelen samen het werk. De focus van de huisarts ligt meer op het medische, die van de verpleegkundige meer op het psychosociale. Al heeft de huisarts de eindverantwoordelijkheid, er is nauwelijks sprake van een hiërarchie en veel wordt samen beslist. Op basis van wat de huisarts over de burger weet, wordt elke burger behorende bij een consultorio jaarlijks ingedeeld in een gezondheidsrisicocategorie ( 1 =gezond, 2 =risico op ziekte, $3=$ ziek, 4 = gehandicapt). In principe ziet de huisarts elke burger minimaal een- tot viermaal per jaar, afhankelijk van de categorie. Door de kleinschaligheid, hun inbedding in de buurt en de jaarlijkse risicostratificatie kennen huisarts en wijkverpleegkundige hun 'patiënten' goed, niet alleen medisch, maar ook psychisch en sociaal. Ze zijn de ogen en oren van de buurt als het om gezondheid en welzijn gaat. Daarbij ligt de focus niet alleen op het individu, maar ook op de familie en de buurt. Voor elk gezinsverband is er een apart dossier. Als bijvoorbeeld een ouder familielid zijn heup breekt, bekommert de specialist zich om de heup en ontfermen de huisarts en wijkverpleegkundige zich om de familie.

De functie van een consultorio ligt tussen die van een Nederlands consultatiebureau en huisartsenpraktijk in. Er is zowel aandacht voor klachten van de patiënt, als een (pro)actieve benadering gericht op gezondheidsbevordering van het individu en de gemeenschap. Zeventig procent van de contacten wordt zelf afgehandeld. Er is sprake van veel vroegsignalering, gezondheidsvoorlichting, begeleiding en ondersteuning, zowel individueel als collectief.

Een groot verschil met Nederland is de wijkpolikliniek. Op gemiddeld tien consultorio's is er een wijkpolikliniek. Kern van deze polikliniek is het multidisciplinaire basisteam met een internist, kinderarts, gynaecoloog, psycholoog, maatschappelijk werker, statisticus, epidemioloog en hygiënist [3]. Naar behoefte wordt het team uitgebreid met professionals uit andere disciplines. Dit kunnen specialisten zijn uit ziekenhuizen of psychiaters uit ggz-instellingen. Specialisten werken zowel in een gespecialiseerde setting als in een wijkpolikliniek. Ze gaan daarnaast ook naar de consultorio en bezoeken mensen thuis. De wijkverpleegkundige en de huisarts houden de regie en zijn onderdeel van de wijkpolikliniek.

Tot slot is er veel aandacht voor terugkoppeling en aanpassing van beleid. Zowel van de huisartsenpraktijk en wijkpolikliniek, als van de verschillende overheden wordt jaarlijks bijgehouden wat de resultaten zijn op het gebied van gezondheid en wat dat voor het komende jaar betekent. Zo had de praktijk die wij bezochten zich tot doel gesteld het aantal mensen met hoge bloeddruk te verkleinen door een geprotocolleerde aanpak.

\section{Preventie en ouderen in Cuba}

Preventie bij ouderen is een integraal onderdeel van het Cubaanse centrale gezondheidsbeleid. Vanwege de toenemende vergrijzing, die leidt tot een toenemende druk op het zorgstelsel, vormt ouderenzorg een van de vijf speerpunten van dit beleid.

De principes van collectieve preventie en integrale zorg worden voor ouderen aangevuld met een jaarlijkse geriatrische evaluatie. Deze is gericht op de geriatrische conditie en op het algemene functioneren, zoals het gezichtsvermogen, gehoor, slapen, financiën en de familiesituatie. 
Bewegen is belangrijk in Cuba. Overal zie je groepjes oefeningen doen. Speciaal voor ouderen zijn er per wijk de circulos de abuelos. Ouderen komen daar wekelijks bij elkaar om onder begeleiding te bewegen, de hersenen te trainen en te mediteren, en voor de gezelligheid. Ook kwetsbare ouderen doen mee. Als ze al niet uit zichzelf komen worden ze daartoe door de consultorio gestimuleerd. Wij hebben een dergelijke bijeenkomst meegemaakt. Onder leiding van een 73jarige werd er hard gewerkt en veel gelachen.

Voor ouderen die minder goed voor zichzelf kunnen zorgen en voor wie de steun van familie of buren ontoereikend is, is er een dagopvang in de wijk, de casa de abuelos. De ouderen krijgen er te eten en worden geactiveerd om lijf en hoofd te bewegen. We hebben een dergelijk huis bezocht. Net als bij de circulos de abuelos vielen ook hier de vriendelijkheid en de actieve manier op waarop de ouderen deelnamen. $\mathrm{Al}$ was er niet alleen vrolijkheid. Als je met ouderen aan de praat raakte merkte je hoeveel verdriet er was, vooral om familie die er niet meer voor ze was, en soms ook om ontoereikende specialistische zorg.

Als ouderen in het ziekenhuis belanden is hun leeftijd nadrukkelijk een aandachtspunt. Elke oudere krijgt een geriatrische evaluatie, die gericht is op functioneren in plaats van genezen en waarbij er aandacht is voor voeding, spierverlies (sarcopenie), sociale contacten en de aanwezigheid van een depressie of dementie.

Als men de diagnose dementie vermoedt komt het systeem gelijk in actie. Van de familie en buren wordt verwacht dat ze de begeleiding op zich nemen. De wijkverpleegkundige of huisarts ondersteunt de familie, onder andere door voorlichting. Zo nodig wordt via de wijkpolikliniek een psycholoog of maatschappelijk werker ingeschakeld.

\section{Cubaanse lessen voor de Nederlandse (ouderen)zorg}

In Nederland is als gevolg van verschillende wetten met eigen besturingssystemen, versterkt door marktwerking en decentralisering, een scheiding ontstaan tussen zorg en welzijn, én tussen hoog specialistische en basiszorg. Huisartsen en wijkverpleging kunnen door eisen van de Mededingingswet maar beperkt wijkgericht werken. Het sociaal domein wordt gestuurd door de gemeente en kent weinig prikkels voor samenwerking met de zorg. Binnen de sectoren en beroepen is de afgelopen dertig jaar een enorme taakdifferentiatie ontstaan, in het bijzonder bij de wijkverpleging. Alles bij elkaar leidt dat tot fragmentatie en gebrek aan samenhang. De armoede in Cuba, gecombineerd met sterk overheidsingrijpen vanuit een duidelijke visie, leidt tot veel meer samenhang en integrale zorg op wijkniveau. Waar Cuba gediend zou kunnen zijn met meer ondernemerschap en technische innovatie, kan Nederland leren van de meer collectief georiënteerde preventieve zorg. Dat vraagt om integraal, kleinschalig en wijkgericht werken, waarbij de sociale context meer in ogenschouw wordt genomen en er meer aandacht is voor sociaal en psychisch welbevinden. Dat vereist een sterke eerste lijn, en de inzet van huisartsen én wijkverpleegkundigen, samen met professionals uit het sociaal domein, zoals maatschappelijk werkers. Samen zijn zij de ogen en oren van de wijk.

We pleiten er hier niet voor het Cubaanse model over te nemen - dat past niet bij onze behoefte aan privacy en de afkeer van top-downbeleid. Maar het kan wel inspireren, bijvoorbeeld door na te denken over andere organisatievormen, zoals integrale wijkklinieken en kleinschalige gecombineerde initiatieven van wijkverpleegkundigen, huisartsen en maatschappelijk werk. In de jaren tachtig van de vorige eeuw hadden we iets wat daarop leek: de hometeams. Daarin werkten huisartsen, wijkverpleegkundigen en maatschappelijk werkers samen in de wijk. Ze stemden niet alleen de zorg af, maar ook hun werkwijze, bijvoorbeeld door gezamenlijke protocollen te maken voor de rol van familie en mantelzorgers. Door andere financiering en taakdifferentiatie zijn deze teams ter ziele gegaan. De laatste tijd zien we oproepen van artsen, verpleegkundigen, verzorgenden en andere werkers in de zorg voor meer samenwerking, preventie en wijkgerichte integrale zorg met aandacht voor de meest kwetsbaren. Goedbedoelde losse initiatieven alleen zijn echter onvoldoende om de zorg te veranderen: ze moeten ondersteund en gestimuleerd worden door financiering en beleid.

De belangrijke les die Cuba ons leert is hoe we weer komen tot de kern van waar het ons allemaal om te doen is: voorkomen van ziekte, stimuleren van gezondheid en aandacht voor kwaliteit van leven in brede zin. Dat vraagt een verandering in het sterk op medicalisering gerichte denken en handelen. Wetten en praktische bezwaren staan daarbij in de weg, maar ook cultuur en menselijk handelen. De combinatie van onze weelde, technische mogelijkheden en de grenzeloze behoefte aan verantwoording heeft ons het zicht ontnomen op waar het werkelijk omgaat: waarden-volle zorg, waarin menselijk contact centraal staat. Dat leert Cuba ons: wat hartelijkheid, aandacht, tijd, muziek en dans met je doen. Je wordt er beter van! 
Open Access This article is licensed under a Creative Commons Attribution 4.0 International License, which permits use, sharing, adaptation, distribution and reproduction in any medium or format, as long as you give appropriate credit to the original author(s) and the source, provide a link to the Creative Commons licence, and indicate if changes were made. The images or other third party material in this article are included in the article's Creative Commons licence, unless indicated otherwise in a credit line to the material. If material is not included in the article's Creative Commons licence and your intended use is not permitted by statutory regulation or exceeds the permitted use, you will need to obtain permission directly from the copyright holder. To view a copy of this licence, visit http://creativecommons.org/licenses/by/4.0/.

\section{Literatuur}

1. Index Mundi. Factbook. Cuba en Nederland. https://www. indexmundi.com/cuba. https://www.indexmundi.com/ netherlands.

2. Visser I, Jonas P. Geboortezorg op Cuba is focussen op preventie. Med Contact. 2018;37:38-42.

3. Turquina González Cárdenas L, Cuesta Mejías L, Pérez Perea L, Presno Labrador MC, Fernández Díaz IE, De la Caridad Pérez Díaz T, et al. El Programa del médico y enfermera de la familia: desarrollo del modelo de atención médica en Cuba. Rev Panam Salud Publica. 2018;42:e31. 